\title{
Oral Propranolol: A Useful Treatment for Infantile Hemangioma
}

\author{
Ahmed Hassan El-Sabbagh \\ Plastic Surgery Center, Faculty of Medicine, Mansoura University, \\ Mansoura, Egypt \\ Email: elsabbagh17@hotmail.com, elsabbagh17@gmail.com
}

Received 30 March 2015; accepted 17 July 2015; published 20 July 2015

Copyright (C) 2015 by author and Scientific Research Publishing Inc.

This work is licensed under the Creative Commons Attribution International License (CC BY). http://creativecommons.org/licenses/by/4.0/

cC) (i) Open Access

\begin{abstract}
Background: Infantile haemangioma is the commonest childhood tumor. Several lines of treatment are available. Recent reports have focused on the value of propranolol in treating rapidly proliferating haemangioma. The aim of this study was to assess oral propranolol in treatment for facial haemangioma. Patients and Methods: Fifteen patients with rapidly proliferating infantile facial haemangioma with cosmetic disfigurement were treated with oral propranolol. All patients had cardiovascular pre-treatment work-up and commenced on oral propranolol at $3 \mathrm{mg} / \mathrm{kg} / \mathrm{day}$. Results: A rapid decrease in hemangioma proliferation was seen in $100 \%$ of patients and significant regressions occuring in all patients. This treatment was well tolerated and had little side effects. Conclusions: Oral propranolol is a reliable and easily reproducible method for treatment of facial hemangioma.
\end{abstract}

\section{Keywords}

Oral Propranolol, Infantile Hemangioma, Medical Treatment

\section{Introduction}

Vascular anomalies are generally classified into two subgroups: vascular tumors (with endothelial proliferation) and vascular malformations (with normal endothelial growth) [1]. Infantile hemangioma is the most common benign tumor affecting $4 \%$ to $10 \%$ of whites, $14 \%$ of black, and $0.8 \%$ of Asian with a female-to-male ratio of 3:1 and predominance in premature infants and Caucasians. Most infantile hemangioma occurs in the head and neck regions [2].

Infantile hemangioma is a disorder of aberrant proliferation and differentiation of primitive neural crest phenotypic cells [3]. They are potentially ruled by the renin-angiotensin system [4]-[7]. 
Several regulators have been hypothesized the process of angiogenesis including the role of the vascular endothelial growth factors (VEGFs) and basic fibroblast growth factor (bFGF) [6].

Infantile hemangioma grows faster than the rate of the child during the (proliferating phase) first 9 months of age. The tumor begins to shrink (involuting phase) followed by a slow inevitable regression (involuted phase) [8].

Although no intervention is required in most cases, functional and cosmetic impairment can sometimes necessitate urgent intervention. A great progress in treating these lesions has occurred, including the use of vincristine, interferon-alpha, systemic corticosteroids, pulsed dye laser, liquid nitrogen cryotherapy, and excisional surgery [9]-[12].

Accidental discovery of accelerated involution of infantile hemangioma induced by propranolol has resulted in a recognized shift in the treatment of disfiguring proliferating infantile hemangioma. Its availability, great potency and lack of major side effects have been documented in succession [13] [14]. In this paper, oral propranolol was used in treating facial infantile hemangioma.

\section{Patients and Methods}

Fifteen patients who met the treatment criteria (Table 1) were admitted to plastic surgery center (Mansoura University Hospital, Mansoura, Egypt and King Salman Hospital (Riyadh, Kingdom of Saudi Arabia) from March of 2012 until February of 2014.) All syndromic cases or hemangiomas associated with visceral lesions were excluded. Only cutaneous hemangiomas were included. Informed consent was obtained from all parents or guardians of children involved in the study. Separate consent for photography was taken from all parents or guardians of children involved in the study. Assessment of patient suitability for propranolol was performed as part of a multidisciplinary team including plastic surgeon, and pediatric cardiologist.

Parents received extensive counseling regarding likely outcomes and possible side effects following oral propranolol treatment as a part of fully informed consent. Data included age, sex, weight, lesion location, size, special investigations, and diagnosis according to clinical history (lesion appears during the first month and it grows rapidly than the growth of the child).

Oral propranolol was administered at $(1 \mathrm{mg} / \mathrm{kg} / \mathrm{day})$ in the first week, increased in the $2^{\text {nd }}$ week to $(2 \mathrm{mg} / \mathrm{kg} /$ day) till reaching the target dose $(3 \mathrm{mg} / \mathrm{kg} / \mathrm{day})$ in the $3^{\text {rd }}$ week. Treatment was stopped after a sustained plateau of the growth of the haemangioma (6 - 8 weeks). Drug was taken in three divided dose/day. Hospital stay was mandatory for a 24-hour during initiation of new dose therapy, with regular hemodynamic monitoring (pulse, blood pressure, respiratory rate, electrocardiogram and echocardiogram). Oral propranolol was available in tablet form that was grinded and dissolved in normal saline according to the desired dose. Through syringe without a needle, the drug was put in mouth of infants. Indications for not giving any further dose are listed in (Table 2). Consideration could be given for a repeat course of propranolol therapy. All patients were treated in the proliferative phase.

\section{Table 1. Inclusion and exclusion criteria.}

Inclusion and exclusion criteria

Inclusion criteria

Any rapidly progressing haemangioma in the face Any functional or significant cosmetic deformity

Exclusion criteria

Any child with a cardiovascular disorder

Significant asthma

Any patient syndromic

Hemangiomas associated with visceral lesions

Table 2. Indications for withholding treatment.

Indications for withholding treatment

1. Symptomatic bradycardia or hypotension

2. Symptomatic hypoglycaemia

3. Symptomatic wheeze 


\section{Clinical Evaluation}

Regression in the size and fading in the color of hemangioma was clinically assessed by an independent physician. This was done before starting treatment as well as at each monthly follow-up visit.

\section{Results}

Patients' demographic data and lesions' data are collectively summarized (Table 3). In total, 15 children were treated with propranolol orally (Figures 1-4). The treatment lasted for a period of 3 to 4 months without major complications. After one week from reaching the target dose $(3 \mathrm{mg} / \mathrm{kg}$ ) a change in color was observed in $100 \%$
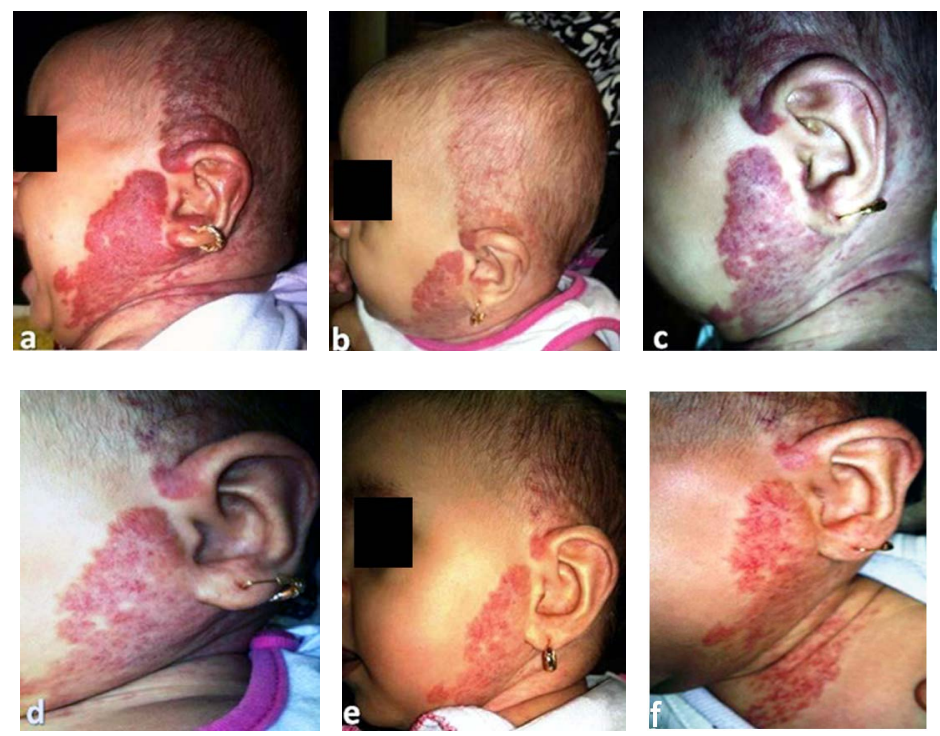

Figure 1. Facial hemangioma of a girl aged 3 months and weighed 6 kg. (a) At admission; (b) after one month; (c) after two months; (d) after three months; (e) after four months; (f) after five months.

\begin{tabular}{|c|c|c|c|c|c|c|c|}
\hline $\begin{array}{l}\text { Patient } \\
\text { number }\end{array}$ & $\begin{array}{l}\text { Age of patient } \\
\text { (months) }\end{array}$ & $\begin{array}{c}\text { Sex of the } \\
\text { patient }\end{array}$ & $\begin{array}{l}\text { Size of lesion } \\
\text { (cm) }\end{array}$ & Site of lesion & $\begin{array}{c}\text { Number } \\
\text { of lesions }\end{array}$ & $\begin{array}{l}\text { Weight } \\
\text { (kg) }\end{array}$ & $\begin{array}{c}\text { Duration of } \\
\text { treatment }\end{array}$ \\
\hline 1 & 3 & Female & $5 \times 7$ & Face & Single & 6 & 3 Months \\
\hline 2 & 3 & Female & $\begin{array}{c}\text { Diffuse lesions } \\
\text { on both sides of face }\end{array}$ & Face & Multiple & 6.5 & 3 Months \\
\hline 3 & 3 & Female & $4 \times 3$ & Face & Single & 7 & 4 Months \\
\hline 4 & 5 & Female & $2 \times 2$ & Nose & Single & 8 & 3 Months \\
\hline 5 & 5 & Female & $3 \times 2.5$ & Scalp & Single & 5.5 & 3 Months \\
\hline 6 & 5 & Female & $\begin{array}{l}\text { Diffuse lesions } \\
\text { on both sides }\end{array}$ & Face & Multiple & 7.5 & 4 Months \\
\hline 7 & 4 & Female & $2 \times 2.5$ & Perioral & Single & 7 & 3 Months \\
\hline 8 & 4 & Female & $2.5 \times 1$ & Scalp & Single & 8 & 3 Months \\
\hline 9 & 3 & Female & $3 \times 1.5$ & Face & Multiple & 6 & 3 Months \\
\hline 10 & 5 & Female & $2 \times 1.5$ & Perioral & Single & 7 & 4 Months \\
\hline 11 & 4 & Female & $\begin{array}{l}\text { Diffuse lesions } \\
\text { on both sides }\end{array}$ & Face & Multiple & 6.5 & 3 Months \\
\hline 12 & 3 & Female & $2 \times 1.5$ & Nose & Single & 5 & 4 Months \\
\hline 13 & 5 & Female & $4 \times 1.5$ & Face & Single & 8.5 & 3 Months \\
\hline 14 & 5 & Female & $3 \times 2$ & Face & Single & 8 & 3 Months \\
\hline 15 & 3 & Female & $\begin{array}{l}\text { Diffuse lesions } \\
\text { on both sides }\end{array}$ & Face & Multiple & 4.5 & 3 Months \\
\hline
\end{tabular}



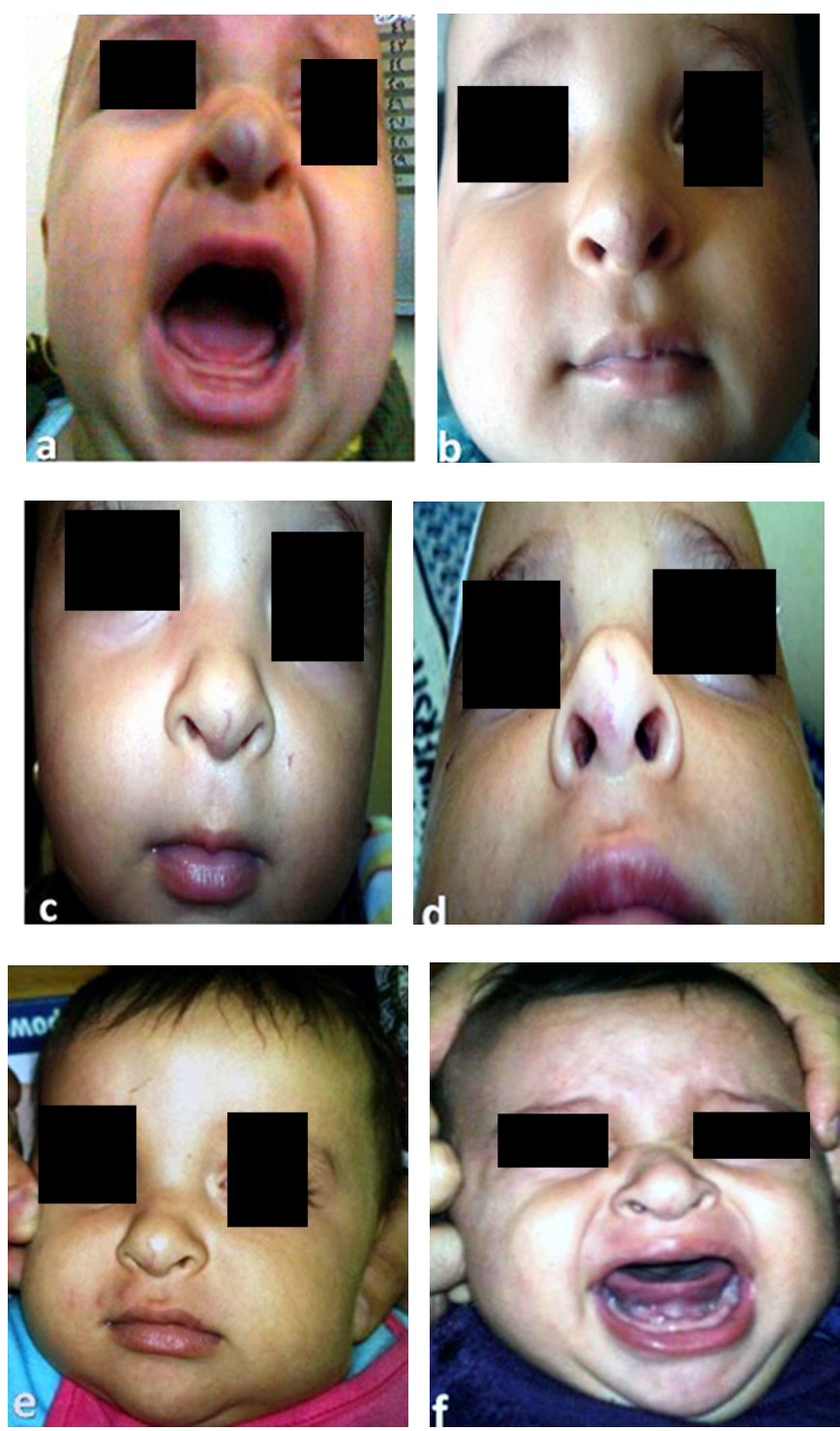

(A)
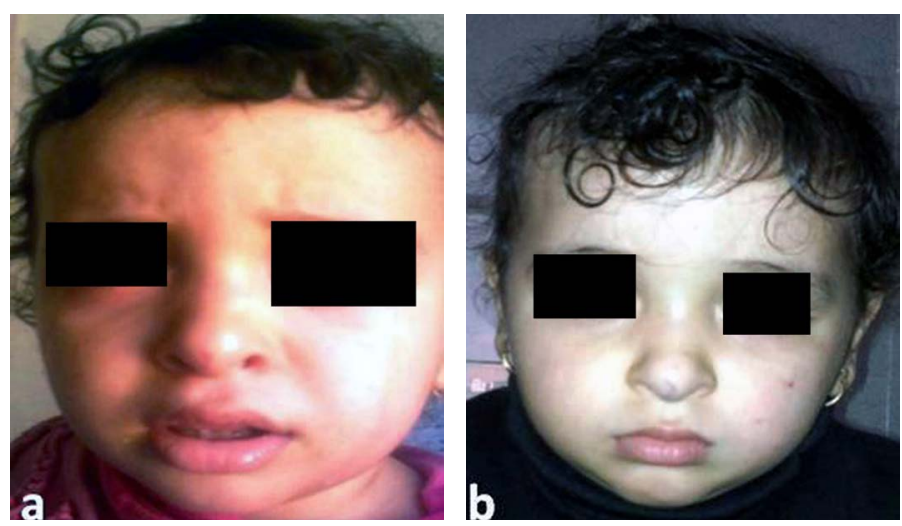

(B)

Figure 2. (A) hemangioma of the nose of a girl aged 5 months and weighed $8 \mathrm{~kg}$. (a) At admission; (b) after one month (c) after two months; (d) after three months; (e) after four months; (f) after five months; (B) Hemangioma of the nose after two years; (a) after 18 months; (b) after two years. 

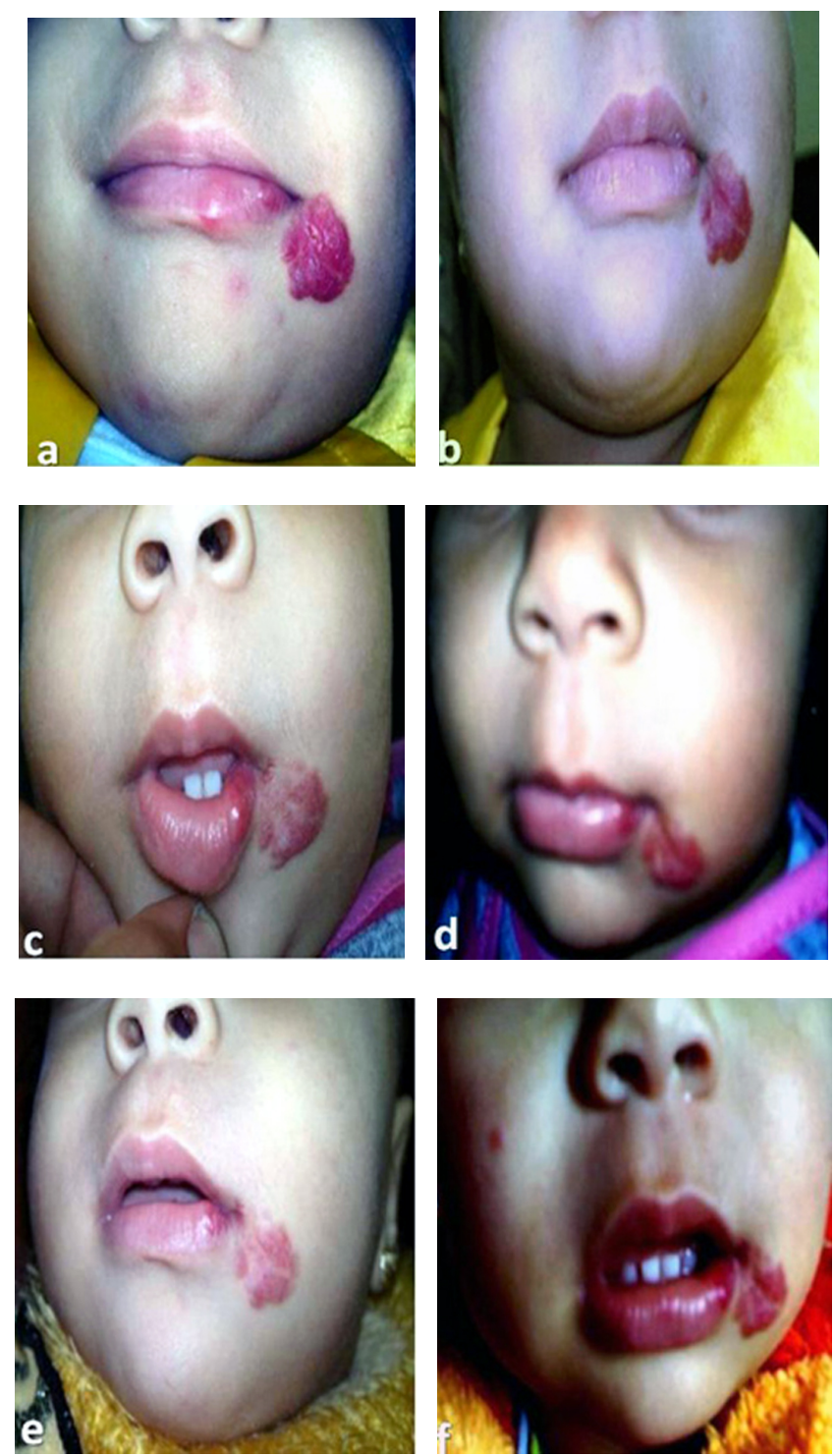

(A)
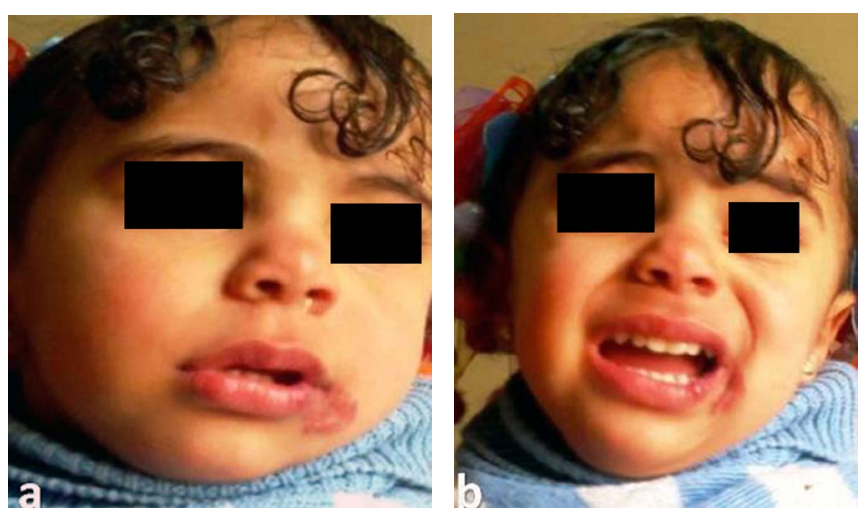

(B)

Figure 3. (A) hemangioma of the perioral area of a girl aged 4 months and weighed $7 \mathrm{~kg}$. (a) at admission; (b) after one month; (c) after two months; (d) after three months; (e) after four months; (f) after five months; (B) Hemangioma of the perioral area after two years. (a) at rest; (b) during crying. 

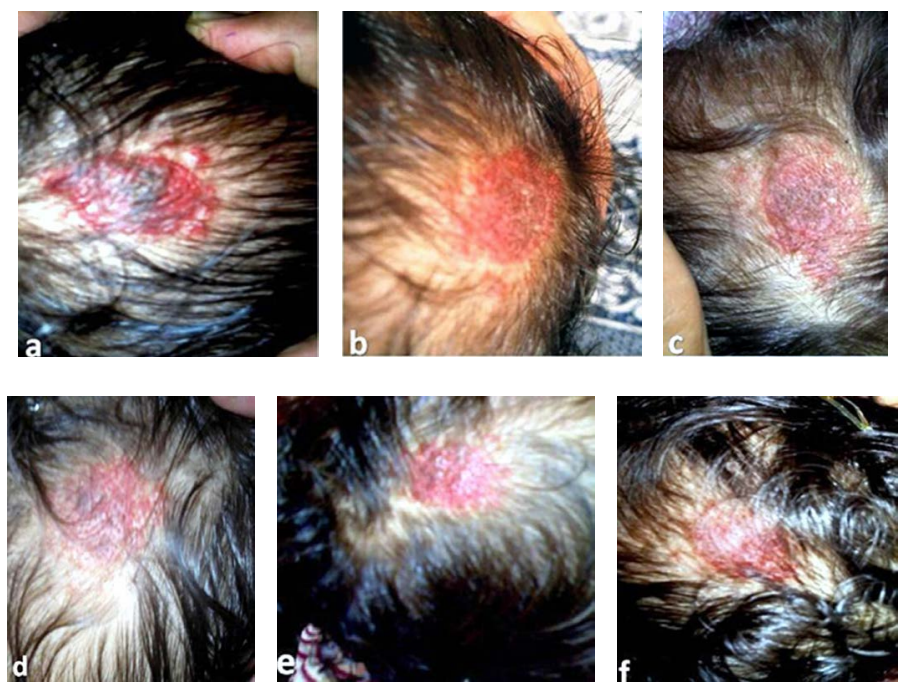

Figure 4. Hemangioma of the scalp of a girl aged 4 months and weighed $8 \mathrm{~kg}$. (a) At admission; (b) after one month; (c) after two months; (d) after three months; (e) after four months; (f) after five months.

of patients, and 2 weeks later, $50 \%$ decreased in diameter of the original lesion was found in half of patients. This may have been related to the thickness of the lesions and the age of the girls. Lesions have evoked dramatic color changes primarily from deep red to purple color, followed by a progressive lightening of hemangiomas color. On cessation of propranolol treatment and follow-up period, hemangiomas had become nearly flat and light in color. Three patients showed signs of palpitation and diarrhea at the beginning of treatment (first month) as reported by their parents. The girls were followed up for two years. No patient needed a second course.

\section{Discussion}

Propranolol as a beta-adrenergic receptor antagonist was discovered by Sir James W. Black. Accidently, a patient was treated with propranolol for cardiomyopathy showed involution of a proliferating hemangioma. Labreze reported the effect of propranolol on a child with a facial haemangioma. Since then many more studies have been reported [13] [14].

Indeed, propranolol has other indications in plastic surgery both clinically and experimentally. Clinically, it was used for rhinoplasty patients who developed a stress in response to the shape of their nose [15]. Administration of a low dose of propranolol improves cutaneous wound healing in burned rats [16].

The mechanism of action of propranolol in infantile hemangioma remains unknown. It has been postulated that hemangiomas regress by vasoconstriction, inhibition of angiogenesis, apoptosis, or a combination of all of these actions [17].

Most infantile hemangiomas are observed early during the proliferative phase. In this series; all cases were managed in the early proliferative phase to limit its growth and functional distortion.

Tan and his colleagues [18] criticized the necessity to use the higher dose range and found a dose of 1.5 $\mathrm{mg} / \mathrm{kg} /$ day was sufficient. Dose of propranolol was reported in the literature as $2-3 \mathrm{mg} / \mathrm{kg} / \mathrm{day}$, initially by the French scientists [13] and subsequently carried with some modifications by Liverpool researchers [19]. In this paper; propranolol dose was increased every week till reaching $3 \mathrm{mg} / \mathrm{kg} /$ day in three divided doses. In the absence of an evidence based medicine, I believed that propranolol administered in divided doses with gradual increase may add safety to avoid any major complications. No recurrence was observed along two years of follow up in this series.

In Egypt, propranolol is not available in a pharmaceutical formula appropriate for infants, and younger children less than 6 years [20]. It was prepared from tablets dissolved to suitable smaller dosages, which may complicate dose adaptation and drug administration. The tablets are available in $10 \mathrm{mg}$ concentration.

First-line treatment for small hemangiomas is intralesional corticosteroid. Oral glucocorticoids and propranolol are reserved for tumors that are too large for injections [21].

Both corticosteroid (Figure 5) and propranolol are equally neck by neck in the management of infantile he- 


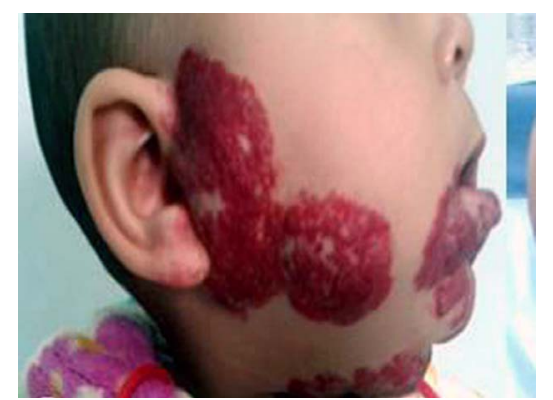

(a)

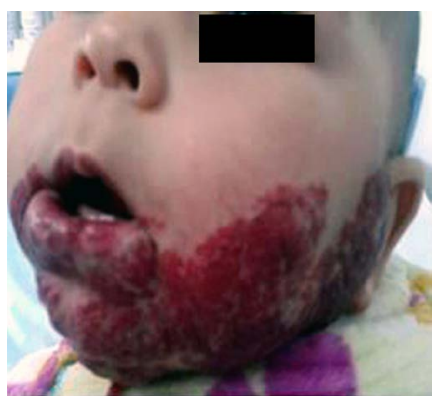

(b)

(A)

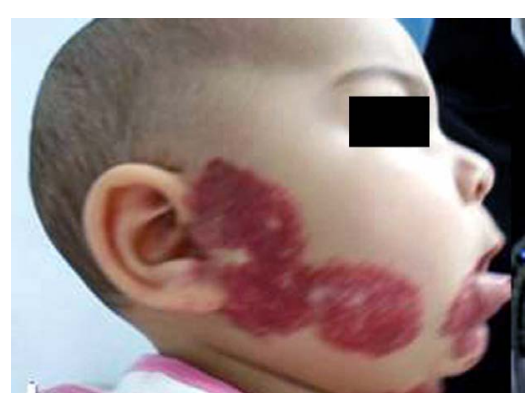

(a)

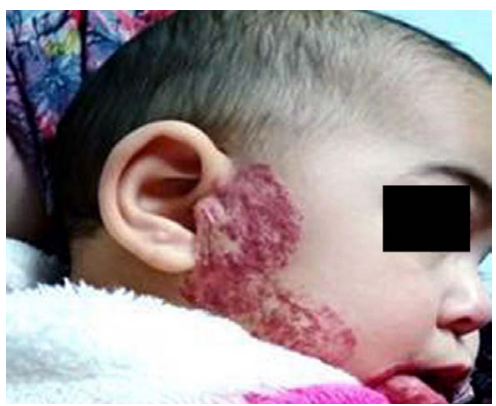

(a)

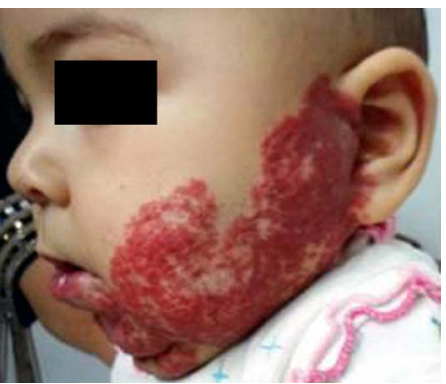

(b)

B)

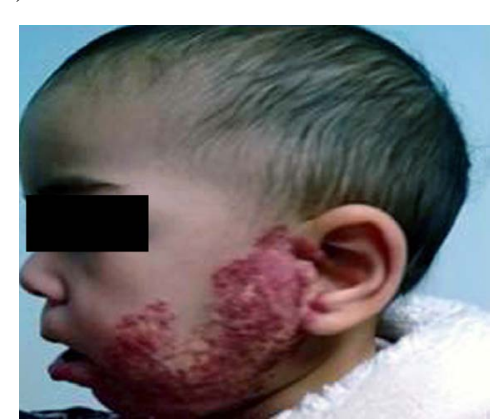

(b)

(C)

Figure 5. Facial hemangioma of a girl aged 6 months and weighed $8.5 \mathrm{~kg}$ treated with corticosteroids. (A) At admission, (a) right side, (b) left side; (B) After one month, (a) right side, (b) left side; (C) After eight months, (a) right side, (b) left side.

mangioma. However, propranolol is well tolerated and is known to have safety in children. In addition, propranolol can be used in non-responsive cases to corticosteroids. Moreover, the side effects of systemic corticosteroids are relatively common. Growth retardation is more common if treatment is started before 3 months of age or continued for 6 months or longer [22].

Resection of a proliferating infantile hemangioma is not recommended because the tumor is highly vascular and the patient is at greater risk for blood loss, and an inferior aesthetic outcome [23].

Hemangiomas of the nasal tip (Cyrano nose) are rare but can have a very profound psychological problem. Also, they give rise to definitive nasal deformations. Surgically, they are always removed incompletely to maintain the tip of the nose [24]. Actually, propanolol produced very promising results (Figure 2).

Regarding the management of lip haemangiomas, debulking strategy adopted by some authors offered excellent results [25]. Early treatment with propranolol may halt the need for surgery and its scars (Figure 3).

Although beta blockers have a good safety reputation in the treatment of young children, this may not be simply extrapolated to infants (some of whom are born prematurely) and young children with infantile hemangioma, who are otherwise normotensive [18]. 
Side effects of propranolol include bradycardia, hypotension and hypoglycemia [26]. During this work, any child with cardiac and /or airway disease was excluded. Only three patients showed signs of palpitation and diarrhea that improved with time.

Ulceration is the most common complication of hemangioma, occurring in $15 \%$ of patients [27]. It is also associated with infection (16\%) and bleeding (41\%). Factors predisposing to ulceration include surface friction and maceration [28]. Several reports have described the beneficial effect of propranolol on ulcerated hemangioma [29] [30]. Fortunately, none of our cases were complicated by ulceration.

A limitation of this study is that large/problematic infantile haemangiomas are not present in the study and limited number of patients. However, tumour size did not influence involution of hemangioma in this series. Also, no radiological assessment was done by sonography or MRI. The aim was to find a cheap, effective and simple treatment not burden by additional investigations. Control group was not included as this study is a case series (evidence base: IV).

In summary, many options for treatments are effective for hemangioma. Their use has been masked by the effective use of propranolol, which causes rapid stoppage of proliferation and promotes decrease of disfiguring hemangioma. The discovery of the role of beta blockers in stem cell may lead to favorable outcome [31].

\section{Conclusion}

On the basis of the limited evidence available, more patients with hemangiomas should be included for primary treatment with propranolol. In this study, oral propranolol was well tolerated, very cheap and proved to be a valuable tool for treatment of facial infantile hemangioma.

\section{Ethical Standards}

This study has been performed in accordance with the ethical standards set forth in the 1964 Declaration of Helsinki and its later amendments. Informed consent was obtained from all parents responsible for participants included in the study.

\section{Disclosure}

We do not have any financial interests or commercial associations to disclose.

\section{References}

[1] Mulliken, J.B. (2008) Color Atlas of Vascular Tumors and Vascular Malformations. Plastic and Reconstructive Surgery, 121, 333. http://dx.doi.org/10.1097/01.prs.0000302375.97376.7f

[2] Kilcline, C. and Frieden, I.J. (2008) Infantile Hemangiomas: How Common Are They? A Systematic Review of the Medical Literature. Pediatric Dermatology, 25, 168-173. http://dx.doi.org/10.1111/j.1525-1470.2008.00626.x

[3] Itinteang, T., Tan, S.T., Brasch, H. and Day, D.J. (2010) Primitive Mesodermal Cells with a Neural Crest Stem Cell Phenotype Predominate Proliferating Infantile Haemangioma. Journal of Clinical Pathology, 63, 771-776. http://dx.doi.org/10.1136/jcp.2010.079368

[4] Itinteang, T., Brasch, H.D., Tan, S.T. and Day, D.J. (2011) Expression of Components of the Renin-Angiotensin System in Proliferating Infantile Haemangioma May Account for the Propranolol-Induced Accelerated Involution. Journal of Plastic, Reconstructive \& Aesthetic Surgery, 64, 759-765. http://dx.doi.org/10.1016/j.bjps.2010.08.039

[5] Mohamed, A.M., Elwakil, T.F., Taher, I.M., Elbarbary, M.M., Kayed, H.F., Hussein, H.A. and Eid, O.M. (2009) Cyclin D1 Gene Amplification in Proliferating Haemangioma. Cell and Tissue Research, 338, 107-115. http://dx.doi.org/10.1007/s00441-009-0858-y

[6] Walter, J.W., North, P.E., Waner, M., Mizeracki, A., Blei, F., Walker, J.W., Reinisch, J.F. and Marchuk, D.A. (2002) Somatic Mutation of Vascular Endothelial Growth Factor Receptors in Juvenile Haemangioma. Genes Chromosomes Cancer, 33, 295-303. http://dx.doi.org/10.1002/gcc.10028

[7] Yu, Y., Fuhr, J., Boye, E., Gyorffy, S., Soker, S., Atala, A., Mulliken, J.B. and Bischoff, J. (2006) Mesenchymal Stem Cells and Adipogenesis in Hemangioma Involution. Stem Cells, 24, 1605-1612. http://dx.doi.org/10.1634/stemcells.2005-0298

[8] Chang, L.C., Haggstrom, A.N., Drolet, B.A., Baselga, E., Chamlin, S.L., Garzon, M.C., Horii, K.A., Lucky, A.W., Mancini, A.J., Metry, D.W., Nopper, A.J., Frieden, I.J., et al. (2008) Growth Characteristics of Infantile Hemangiomas: Implications for Management. Pediatrics, 122, 360-367. http://dx.doi.org/10.1542/peds.2007-2767 
[9] Drolet, B.A., Esterly, N.B. and Frieden, I.J. (1999) Hemangiomas in Children. The New England Journal of Medicine, 341, 173-181. http://dx.doi.org/10.1056/NEJM199907153410307

[10] Fawcett, S.L., Grant, I., Hall, P.N., Kelsall, A.W. and Nicholson, J.C. (2004) Vincristine as a Treatment for a Large Haemangioma Threatening Vital Functions. Brazilian Journal of Probability and Statistics, 57, 168-171.

[11] Batniji, R.K., Buckingham, E.D. and Williams, E.F. (2005) An Aesthetic Approach to Facial Hemangiomas. Archives of Facial Plastic Surgery, 7, 301-306. http://dx.doi.org/10.1001/archfaci.7.5.301

[12] Williams, E.F., Stanislaw, P., Dupree, M., Mourtzikos, K., Mihm, M. and Shannon, L. (2000) Hemangiomas in Infants and Children: An Algorithm for Intervention. Archives of Facial Plastic Surgery, 2, 103-111. http://dx.doi.org/10.1001/archfaci.2.2.103

[13] Leaute-Labreze, C., Dumas de la Roque, E., Hubiche, T., Boralevi, F., Thambo, J.B. and Taïeb, A. (2008) Propranolol for Severe Hemangiomas of Infancy. New England Journal of Medicine, 358, 2649-2651. http://dx.doi.org/10.1056/NEJMc0708819

[14] Michel, J.L. and Patural, H. (2009) Response to Oral Propranolol Therapy for Ulcerated Hemangiomas in Infancy. Archives de Pédiatrie, 16, 1565-1568. http://dx.doi.org/10.1016/j.arcped.2009.09.008

[15] Gruber, R.P., Roberts, C., Schooler, W. and Pitman, R.K. (2009) Preventing Postsurgical Dissatisfaction Syndrome after Rhinoplasty with Propranolol: A Pilot Study. Plastic and Reconstructive Surgery, 123, 1072-1078. http://dx.doi.org/10.1097/PRS.0b013e318199f63f

[16] Romana-Souza, B., Nascimento, A.P. and Monte-Alto-Costa, A. (2008) Low-Dose Propranolol Improves Cutaneous Wound Healing of Burn-Injured Rats. Plastic and Reconstructive Surgery, 122, 1690-1699. http://dx.doi.org/10.1097/PRS.0b013e31818cbf67

[17] Storch, C.H. and Hoeger, P.H. (2010) Propranolol for Infantile Haemangiomas: Insights into the Molecular Mechanisms of Action. British Journal of Dermatology, 163, 269-274. http://dx.doi.org/10.1111/j.1365-2133.2010.09848.x

[18] Tan, S.T., Itinteang, T. and Leadbitter, P. (2010) Low-Dose Propranolol for Infantile Haemangioma. Journal of Plastic, Reconstructive \& Aesthetic Surgery, 64, 292-299. http://dx.doi.org/10.1016/j.bjps.2010.06.010

[19] Holmes, W.J., Mishra, A., Gorst, C. and Liew, S.H. (2011) Propranolol as First-Line Treatment for Rapidly Proliferating Infantile Haemangiomas. Journal of Plastic, Reconstructive \& Aesthetic Surgery, 64, 445-451. http://dx.doi.org/10.1016/j.bjps.2010.07.009

[20] Talaat, A.A., Elbasiouny, M.S., Elgendy, D.S. and Elwakil, T.F. (2012) Propranolol Treatment of Infantile Hemangioma: Clinical and Radiologic Evaluations. Journal of Pediatric Surgery, 47, 707-714. http://dx.doi.org/10.1016/j.jpedsurg.2011.10.058

[21] Greene, A.K. (2011) Management of Hemangiomas and Other Vascular Tumors. Clinics in Plastic Surgery, 38 , 45-63. http://dx.doi.org/10.1016/j.cps.2010.08.001

[22] Boon, L.M., MacDonald, D.M. and Mulliken, J.B. (1999) Complications of Systemic Corticosteroid Therapy for Problematic Hemangioma. Plastic and Reconstructive Surgery, 104, 1616-1623. http://dx.doi.org/10.1097/00006534-199911000-00002

[23] Spector, J.A., Blei, F. and Zide, B.M. (2008) Early Surgical Intervention for Proliferating Hemangiomas of the Scalp: Indications and Outcomes. Plastic and Reconstructive Surgery, 122, 457-462. http://dx.doi.org/10.1097/PRS.0b013e31817d5fa2

[24] Hamou, C., Diner, P.A., Dalmonte, P., Vercellino, N., Soupre, V., Enjolras, O., Vazquez, M.P. and Picard, A. (2010) Nasal Tip Haemangiomas: Guidelines for an Early Surgical Approach. Journal of Plastic, Reconstructive \& Aesthetic Surgery, 63, 934-939. http://dx.doi.org/10.1016/j.bjps.2009.05.020

[25] Chang, C.S., Wong, A., Rohde, C.H., Ascherman, J.A. and Wu, J.K. (2012) Management of Lip Haemangiomas: Minimizing Peri-Oral Scars. Journal of Plastic, Reconstructive \& Aesthetic Surgery, 65, 163-168. http://dx.doi.org/10.1016/j.bjps.2011.08.033

[26] Lawley, L.P., Siegfried, E. and Todd, J.L. (2009) Propranolol Treatment for Hemangioma of Infancy: Risks and Recommendations. Pediatric Dermatology, 26, 610-614. http://dx.doi.org/10.1111/j.1525-1470.2009.00975.x

[27] Metz, B.J., Rubenstein, M.C., Levy, M.L. and Metry, D.W. (2004) Response of Ulcerated Perineal Hemangiomas of Infancy to Becaplermin Gel, a Recombinant Human Platelet-Derived Growth Factor. Archives of Dermatology, 140, 867-870. http://dx.doi.org/10.1001/archderm.140.7.867

[28] Chamlin, S.L., Haggstrom, A.N., Drolet, B.A., Baselga, E., Frieden, I.J., Garzon, M.C., Horii, K.A., Lucky, A.W., Metry, D.W., Newell, B., Nopper, A.J. and Mancini, A.J. (2007) Multicenter Prospective Study of Ulcerated Hemangiomas. The Journal of Pediatrics, 151, 684-689.

[29] Sans, V., de la Roque, E.D., Berge, J., Grenier, N., Boralevi, F., Mazereeuw-Hautier, J., Lipsker, D., Dupuis, E., Ezzedine, K., Vergnes, P., Taïeb, A. and Léauté-Labrèze, C. (2009) Propranolol for Severe Infantile Hemangiomas: Fol- 
low-Up Report. PEDIATRICS, 124, e423-e431. http://dx.doi.org/10.1542/peds.2008-3458

[30] Naouri, M., Schill, T., Maruani, A., Bross, F., Lorette, G. and Rossler, J. (2010) Successful Treatment of Ulcerated Haemangioma with Propranolol. Journal of the European Academy of Dermatology and Venereology, 24, 1109-1112.

[31] Itinteang, T., Withers, A.H., Leadbitter, P., Day, D.J. and Tan, S.T. (2011) Pharmacologic Therapies for Infantile Hemangioma: Is There a Rational Basis? Plastic and Reconstructive Surgery, 128, 499-507. http://dx.doi.org/10.1097/PRS.0b013e31821b63a0 